Навчання вмінню обрати потрібні мовні засоби для реалізації мети висловлювання представляється надзвичайно важливим, оскільки воно пов'язане $з$ підвищенням прагматичної компетенції мовця нерідною мовою.

\title{
Література:
}

1. Янко Т. Е. Коммуникативные стратегии русской речи. М. : Языки славянской культуры, 2001. 384 с.

2. Смирницкий А. И. Синтаксис английского языка. М. : Изд-во литературы на иностр. яз., 1957. 285 с.

3. Торсуева И. Г. Интонация и смысл высказывания. М. : Наука, 1979. $112 \mathrm{c}$.

4. Зіндер Л. Р. Общая фонетика. М.: Высшая школа, 1979. 312 с.

5. Ніколаєва Т. М. «Экстренное введение в ситуацию»: особый вид просодического выделения // Теория языка. Методы его исследования и преподавания. Л., 1981. С. 182-187.

6. Zubizarreta M. L. Prosody, Focus, and Word Order. Cambridge: MIT Press, 1998. 153 p.

DOI https://doi.org/10.30525/978-9934-588-90-7-36

\section{КОМІЧНЕ ПОРТРЕТУВАННЯ ПЕРСОНАЖІВ Е. А. ПОУ ТА М. ГОГОЛЯ: МОВНО-СТИЛІСТИЧНІ ПРІОРИТЕТИ}

\author{
Долгушева О. В. \\ кандидат філологічних наук, \\ доцент кафедри англійської мови та методики ії викладання \\ Центральноукраїнський державний педагогічний університет \\ імені Володимира Винниченка \\ м. Кропивницький, Украӥна
}

Сучасна парадигма філологічних розвідок вирізняється антропоцентричним спрямуванням своїх наукових пошуків. Образ людини як творця і носія мови, у якому моделюється специфіка індивідуальної та колективної свідомості, віддзеркалюються світоглядні орієнтири, емоційні стани й інтелектуальні прояви тощо, постає об'єктом багатьох наукових пошуків. У художніх творах портретні образи демонструють авторський погляд на певні суспільно вагомі риси особистостей, а також розкривають потенціал лінгво-стилістичних засобів тієї чи іншої мови. 
Лінгвістичні аспекти портретних характеристик персонажів привертали увагу Борисової Т.С. [1], Бохун Н.В. [2], Грижак Л.М. [3], Мусурівської О.В. [4], Насалевич Т.В. [5], Омецинської О.В. [6], інших дослідників. Утім, недостатньо висвітленим залишається питання мовностилістичних пріоритетів у створенні комічних образів Едгаром Поу та Миколою Гоголем. Цим і окреслюється актуальність цієї роботи.

Метою $є$ визначення мовно-стилістичних засобів створення комічних портретних характеристик у прозових творах Е.А. Поу та М. Гоголя. Об'єктом дослідження є портретний опис; предмет дослідження - мовні й стилістичні прийоми художнього портретування.

Едгар Аллан Поу та Микола Гоголь вирізняються здатністю майстерно наділяти героїв своїх оповідань тими чи тими рисами. Не $є$ винятком i комічне зображення персонажів, що виявляється у їх зовнішній характеристиці, рисах характеру, світоглядних позицій тощо.

Е. Поу найбільш яскравої характеристики надає персонажам саме комічних оповідань. Перше з них, яке привертає увагу - «The Spectacles». Головного героя цього твору автор характеризує за допомогою таких засобів художньої виразності, як епітети: «а handsome face», «sufficiently good nose», комічність яких у тому, що герой сам самовпевнено використовує їх по відношенню до себе.

Про емоційний стан закоханого героя можемо судити 3 паралельних конструкцій, що створюють ефект градації його усвідомлення цього почуття: "I saw - I felt - I knew that I was deeply, madly, irrevocably in love». Також на позначення закоханості персонажа Поу вдається до метафор: "I was thus wrapped in admiration of this lovely vision», "my illimitable ecstasy of heart»; епітетів: «my burning gaze», «it was love supreme-indescribable». Тут читач стикається 3 повчальним висміюванням наслідків небажання героя носити окуляри, завдяки яким він би уникнув абсурдного шлюбу зі старою дамою. III портретування найяскравіше здійснюється за допомогою епітетів: "a female, the most exquisite I had ever beheld», "the form was divine», "a lovely form in woman», "the beau ideal», "magnificent proportion», "queenly apparition»; метафор: «the necromancy of female gracefulness», "pearly teeth». Іронічне змалювання тут зорієнтоване на демонстрацію спотвореного сприйняття героєм цієї жінки через його небажання носити окуляри. Коли у розв'язці твору герой надіває окуляри, побачене шокує його, що виражене емоційним вигуком персонажа: «My goodness gracious me! - why, what can be the matter with these glasses?». Завдяки саме цим окулярам усе стає на свої місця і виявляється, що «красуні», з якою побрався цей персонаж, 82 роки (а не 27, як думав він), і що діяла вона таким чином, аби провчити його. Попри комічність самого героя та ситуації, твір має дидактичну спрямованість - у кінці оповідання герой робить відповідні 134 
висновки: «I am done forever with billets doux and am never to be met without SPECTACLES».

Серед особливостей іншого комічного оповідання Е. Поу «The Angel of the Odd»- діалог героя з самим собою, у ході якого читач дізнається про сприйняття персонажа самого себе. Тут, шляхом епітетного змалювання («a reflecting intellect», «contemplative understanding») герой сам визначає свої розумові здібності, будучи у стані алкогольного сп'яніння, що свідчить про його дещо завищену самооцінку, адже він хизується своєю перевагою над героями газети, яку він намагається читати. Комічний ефект посилюється постійним повторенням займенників: «like mine», "as I myself possess», "I intend to believe».

Задля створення образу нереального, уявного персонажа Ангела Дивовижного, Е. Поу вдається до оригінального лінгвістичного прийому - вкладає в його вуста особливу, вигадану мову, що чимось нагадує суміш англійської та німецької. Приміром, «Mein Gott, den, vat a vool you bees for dat!». Посилюється комічний ефект завдяки порівнянням ( «уоu mus pe so dronk as de pig, den for not zee me as I zit here at your zide», "you mos pe pigger vool as de goose, for to dispelief vat iz print in de print»), які дотепно змальовують стан сп'яніння головного героя. Сам герой описує незвичну зовнішність Ангела Дивовижного дуже красномовно за допомогою заперечних префіксів: «a personage nondescript, although not altogether indescribable».

Подібно до американського письменника, М. Гоголь для художньої презентації комічного в портретуванні персонажів використовує різні засоби художньої виразності. У передмові до першої частини книги «Вечори на хуторі поблизу Диканьки» автор комічно змальовує образ дяка. Такого ефекту письменник досягає надмірною деталізацією, протиставленнями та порівняннями: «Bom, например, знаете ли вы дьяка диканьской церкви, Фому Григорьевича? Эх, голова! <..> Он никогда не носил пестрядевого халата, какой встретите вы на многих деревенских дьячках; но заходите к нему и в будни, он вас всегда примет в тонком суконном балахоне, цвету застуженного картофельного киселя, за которое платил он в Полтаве чуть не по шести рублей за аршин, складывал его снова, по обыкновению, в двенадцатую долю, и прятал в nазуху». 3 одного боку цей персонаж викликає повагу у односельців, а 3 іншого - його надмірна манірність та увага до власної особи - предмет висміювання.

Зчаста письменник вдається до порівнянь персонажів із інфернальними героями. Завдяки цьому самі дійові особи, розмови між персонажами набувають комічного забарвлення: «- Жаль же, что ты не припомнишь Голопупенкова сына!- A ты будто Охримов сын?- А кто ж? Разве один только льсый дидько, если не он». Водночас автор також 
створює образ народу, показує обрядове дійство під час весілля, коли підсвідомо бажаючи подолати страх перед нечистою силою, люди перевдягалися в інфернальних героїв і влаштовували виставу: «Начнут, бывало, наряжаться в хари - Боже ты мой, на человека не похожи! $<\ldots>$ вот, бывало, один оденется жидом, а другой чертом, начнут сперва целоваться, а после ухватятся за чубы <..> Бог с вами! смех нападет такой, что за живот хватаешься. Пооденутся в туреикие и татарские платья: все горит на них, как жар <... . А как начнут дуреть да строить штуки... ну, тогда хоть святых выноси».

Задля яскравого портретування героїв український митець слова вдається до: епітетів зі зменшувально-пестливими суфіксами («низенький, толстенький человечек»); метафор («сказал винокур, которого щеки в продолжение всего этого разговора беспрерывно заряжсались дымом, как осадная пушка, и губы, оставив коротенькую люльку, выбросили целый облачный фонтан»); порівнянь та персоніфікацій («Под носом торчали у него коротенькие и густые усы; но они так неясно мелькали сквозь табачную атмосферу, что казались мыцью, которую винокур поймал и держал во рту своем, подрывая монополию амбарного кота»).

На загал нами було виокремлено 85 прикладів засобів створення «комічного» у змалюванні персонажів Е. Поу (36) та М.Гоголем (49). Серед засобів портретування розглядалися не лише стилістичні прийоми, а й специфічні текстуальні засоби образотворення, як то деталізація, обрамлення, уведення співставлення з інфернальними героями тощо. Для створення комічних образних характеристик героїв (риси характеру, психологічний стан персонажів) у Е. Поу найчастіше функціонують епітети (36,11\%), паралельні конструкції (16,67\%) та метафори (14,29\%). У М. Гоголя найчастотнішими засобами, вжитими з метою створення комічного у зовнішності чи характері героїв, $\epsilon$ порівняння $(26,5 \%)$, метою яких $є$ створення непрямих образних характеристик.

\section{Література:}

1. Борисова Т.С. Лингвостилистические средства создания образа стереотипного персонажа (на материале англоязычной приключенческой прозы 19-20 веков): дисс. ... канд. филол. наук: спец. 10.02.04. Херсон, 2002. $226 \mathrm{c}$.

2. Бохун Н.В. Мовностилістичні особливості створення портрета персонажа в іспанській художній літературі XIX-XX століть : автореф. дис. ... канд. філол. наук: спец. 10.02.05. Київ, 2007. 20 с.

3. Грижак Л.М. Мовні особливості портретних описів в англійській художній прозі 16 століття. Лінгвокогнітивні та соціокультурні аспекти комунікації: матеріали III Міжнарод. наук.-практ. заочн. конф. 136 
(17 жовтня 2014 р.). Острог: Острозька академія, 2014. URL: http://naub.oa.edu.ua/2014/movni-osoblyvosti-portretnyh-opysiv-v-anhlijskijhudozhnij-prozi-16-stolittya/

4. Мусурівська О.В., Присакару О.С. Лексичні особливості портретних описів у сучасному англомовному художньому дискурсі. Науковий вісник Міжнародного гуманітарного університету. 2016. № 22. C. 122-124.

5. Насалевич Т.В. Портретний опис у різних типах тексту : автореф. дис. ... канд. філол. наук: спец.:10.02.04. Одеса, 2003. 16 с.

6. Омецинська О.В. Особливості порівняння у портретному описі : (на матеріалі англомов. проз. творів першої половини XX ст.). Вісник Харківського національного університету ім. В.Н. Каразіна. 2010. № 930. C. $170-174$.

\title{
Джерела фактичного матеріалу:
}

1. Poe, E.A. Complete Short Stories and Poems. N.Y.: Doubleday, 1984. $832 \mathrm{p}$.

2. Гоголь Н.В. Вечера на хуторе близ Диканьки. Миргород. Повести. Харків: Прапор, 1987. 347 с.

DOI https://doi.org/10.30525/978-9934-588-90-7-37

\section{ЛІНГВАЛЬНІ ШАБЛОНИ НЕКОНКРЕТНОГО МОВЛЕННЯ}

\author{
Карпенко М. Ю. \\ кандидат філологічних наук, \\ дочент кафедри граматики англійської мови \\ Одеський національний університет імені I. І. Мечникова \\ м. Одеса, Україна
}

Актуальність даної розвідки базується на значній науковій увазі дослідників до лінгвальних механізмів сугестії (Т.Ю. Ковалевська, H.B. Кутуза, M. Erickson, R. Bandler, J. Grinder та ін.), проте детальне й всеосяжне дослідження специфіки гіпнотичного дискурсу є нагальною потребою в науковому суспільстві. Метою даного дослідження $є$ опис певних лінгвальних шаблонів англомовної гіпнотичної комунікації. Об'єктом дослідження було обрано гіпнотичний дискурс англійської мови, а предметом - механізми конструювання гіпнотичного комунікативного акту в англійській мові. Матеріалом послугували записи мовлення гіпнотерапевтів під час гіпнотичних сеансів англійською мовою сумарним обсягом близько 50 годин. 